\title{
Knocking On The EU's Door: The Political Economy of EU-Ukraine Relations
}

\section{Marco Montanari}

\section{Introduction}

The events related to the 2004 Ukraine's presidential election (the so-called "Orange Revolution") brought this country, and especially its prospects of becoming a fully-fledged democracy, to the international community's attention. In such a context, the issue of integration with the European Union (EU) is becoming more and more relevant. So far, the relations between the EU and Ukraine have been regulated by a Partnership and Cooperation Agreement, entered into force in 1998. It provides for cooperation in a wide range of areas, including political dialogue, trade, investment, economic and legislative cooperation, and cultural and scientific cooperation.

Following the 2004 Eastern enlargement, the EU launched the European Neighbourhood Policy (ENP), which offers 'the prospect of a stake in the EU Internal Market' (European Commission 2004: 13) to all countries located near the borders of the EU which have not been granted the prospect of future membership. ${ }^{1}$ In the long term, the final goal of the ENP might be that of reaching with these countries a level of integration similar to the present European Economic Area (EEA).

Applying the ENP to Ukraine raises some interesting political economy issues. What are the main interests at stake, on both the EU and the Ukrainian sides, and the main challenges in this integration process? Can the ENP be a credible alternative to full EU membership? This paper seeks to answer these questions by using a liberal intergovernmentalist approach (Moravcsik 1993, 1998), emphasising, first of all, domestic economic interests and, secondly, geopolitical motives as the main determinants of countries' preferences in international negotiations. More specifically, we discuss potential benefits and costs for both EU member states and Ukraine associated to three different scenarios, characterised by an increasing degree of integration: free trade area (FTA), fully developed ENP and EU membership.

Two main conclusions can be drawn from this analysis. First, potential benefits from integration would be asymmetrically distributed, being more significant for Ukraine than for the EU; moreover, the main obstacles to integration would not be economic, but political. Second, the ENP lacks attractiveness in the long term because it would impose obligations analogous to those of EU membership on Ukraine, but without the corresponding benefits; thus the integration process is likely either to produce a more modest outcome, limited to the creation of an FTA, or to lead to EU accession.

The paper is structured as follows. Section 2 briefly describes the main features of the ENP with reference to Ukraine. Section 3 presents a liberal intergovernmentalist framework for the analysis of EU-Ukraine integration. Section 4 applies such theoretical framework to the three different scenarios of integration mentioned above. Section 5 concludes. 


\section{The nature of EU-Ukraine relations in the light of the ENP}

The relations between the EU and Ukraine have been regulated so far through the contractual framework provided by the Partnership and Cooperation Agreement, which was concluded in 1994 and entered into force in March 1998. The most relevant provisions concern the economic sphere. The parties accord to one another Most Favoured Nation treatment and limit the possibility of imposing restrictions on imports and exports, while specific articles govern conditions for establishment and operation of companies, approximation of legislation, intellectual property rights and trade defence instruments.

Even if EU imports of manufactured goods from Ukraine are to a large extent liberalised, special agreements still govern trade in some sensitive products, namely steel and textiles. Trade in certain steel products is currently regulated by a quota system to be replaced by a new agreement, the negotiations of which were completed on 31 March 2005. Reciprocal liberalisation of trade in textile products started from 1 January 2001. A new bilateral agreement, abolishing import and export licensing requirements for all textiles, was signed on 9 March 2005 (European Commission 2005d). With regard to agricultural trade, Ukraine does not benefit from any EU preferential scheme and in some instances still faces relatively high tariff barriers.

Following the 2004 Eastern enlargement, the EU began to develop the ENP as a means to enhance relations with those countries that are located near its borders, but do not currently have the prospect of membership. Through it, the EU is going to offer a more intensive political dialogue and greater access to its programmes and policies (European Commission 2004).

In more detail, in the political field the ENP should lead to intensified relations, including cross border co-operation and shared responsibility in conflict prevention and conflict resolution. The most significant elements of the ENP, however, focus on the economic field. They include:

a) enhanced trade integration; in the case of Ukraine, that imply the possible establishment of an FTA;

b) the prospect of participating in the EU Internal Market and in selected EU programmes in the areas of research and education;

c) increased financial and technical assistance;

d) improved interconnection with the EU in sectors like energy, telecommunication and transport.

To implement the ENP, the method proposed by the European Commission is to define, together with partner countries, a set of priorities, whose fulfilment would bring them closer to the EU. These priorities are to be incorporated in jointly agreed Action Plans, defining a number of key areas for specific short- and medium-term action. After the presentation of a Strategy Paper by the European Commission in May 2004, the Action Plan for Ukraine, covering a three-year period, was jointly adopted at a special EU-Ukraine Co-operation Council on 21 February 2005. Moreover, on the same day, the EU General Affairs and External Relations Council agreed ten specific measures for closer co-operation in order to foster the process of democratisation and economic reform following the 2004 Orange Revolution. They cover, inter alia, issues such as foreign and security policy, visa facilitation, Ukraine's accession to the World Trade Organization (a key condition to be satisfied before possible negotiations for an FTA may start) and financial assistance (European Commission 2005c).

The 2004 ENP Strategy Paper envisages that, when Action Plan priorities are met, the following step could consist in the negotiation with each partner country of a bilateral European Neighbourhood Agreement, which, in Ukraine's case, would replace the present Partnership and Co-operation Agreement. Progress made in the implementation of the Action Plans should therefore enable the EU and its partners to agree on longer term goals for further development of relations in the years ahead. 
The long-term implications of the ENP are therefore still characterised by quite a large degree of vagueness and uncertainty. It is worth noting that the early 2003 Commission proposals explicitly suggested that the ENP would promote the "four freedoms" (concerning movement of persons, goods, services and capital) on which the Single Market is based, in return for approximation of partner countries' legislation with that of the EU (European Commission 2003). The final outcome would be a degree of economic integration comparable to the present EEA. By contrast, the 2004 Strategy Paper makes no direct reference to that and only focuses on the medium-term Action Plans instead (Moshes and Haukkala 2004). Because of this shift of emphasis, Vahl (2005) argues that 'it is clear that the extent of economic integration through the ENP has been scaled down and will fall far short of the EEA' (p. 9).

Whilst this appears true if the perspective is restricted to the time span covered by the Action Plans, however the chance of negotiating new European Neighbourhood Agreements may still open the door to deeper integration in the long run, including a progressive establishment of the "four freedoms". In other words, the ENP looks like an open-ended process. Its ambiguity will dissipate only when the EU makes clear what 'the prospect of a stake in the EU Internal Market' ultimately means.

\section{Liberal intergovernmentalism and EU-Ukraine relations: a conceptual framework}

In this section a theoretical framework is provided which allows for the analysis of the prospects of Ukraine's economic and political integration with the EU. To do so, this paper draws upon liberal intergovernmentalism, a theory developed by Andrew Moravcsik (1993, 1998), which seeks to explain the major turning points in European integration history. Very concisely, it proposes a three-level analysis of the European integration process focusing on the formation of national preferences, the outcome of intergovernmental bargaining and the subsequent choice of international institutions.

A liberal intergovernmentalist approach is also suitable for the analysis of EU agreements with third countries, because both association agreements (according to Art. 300 and Art. 310 of the EC Treaty) and accession to the EU (under Art. 49 of the EU Treaty) require unanimity among member states and therefore may fit into the category of interstate bargaining. With regard to the former, theoretical frameworks drawing on liberal intergovernmentalism have been recently used to analyse, for instance, the 2000 Cotonou Agreement with the African, Caribbean and Pacific countries (Forwood 2001) and the Euro-Mediterranean Association Agreements with the Southern Mediterranean countries (Montanari 2007). As regards the latter, Moravcsik and Vachudova (2003) and, partially, Schimmelfennig (2001) employ liberal intergovernmentalism to account for the EU Eastern enlargement process.

The first two levels of liberal intergovernmental analysis are those relevant for the model of EU-Ukraine relations, as set out in this paper: how domestic groups' interests translate into state preferences and how the outcome of international negotiations is shaped according to the relative bargaining power of the players involved. Negotiations leading to international agreements take place therefore at two levels: within countries, involving domestic groups with different interests, and among states. At the national level, domestic groups pursue their interests by lobbying the government to adopt a position favourable to them, then, at the international level, the aim of national governments is to maximize their ability to defend domestic interests. Since most EU activities belong to the economic sphere, domestic interests are principally economic, but also geopolitical concerns may play a significant role. Before proceeding further, we have to define better what we mean by 'international level' when the EU negotiates with a third country. It includes two distinct phases, taking place sequentially: first, bargaining among EU member states in order to find a common position vis-à-vis the partner country, then, negotiations with that country to conclude a bilateral agreement.

However, governments are not always so strictly constrained by domestic actors. There are at least two kinds of situations where they can find more room for manoeuvre. The first is when 
the future effects of a specific policy are uncertain. 'Uncertainty about the effects of cooperation arises where policies are stated vaguely, left to future negotiation, mediated by complex market processes, or applied in an unpredictable way across a population. Uncertain policies engender less opposition than those that are immediate, precise and targeted' (Moravcsik 1993: 490). The second arises when an issue is perceived as not very salient from a political economy viewpoint. 'When net expected costs are insignificant, ambiguous, balanced or uncertain, governments enjoy a greater autonomy from particularistic domestic groups that oppose co-operation' (Moravcsik 1993: 490).

When moving from the domestic to the international level, the theory has to explain how intergovernmental bargaining are shaped. Here the fundamental concept is "asymmetrical interdependence", firstly introduced by Keohane and Nye (1977): the states which are going to gain the most from international co-operation are more willing to compromise. Therefore, countries expecting to get large benefits have the most intense preferences for agreement and are disposed to make concessions in order to reach it, because it would still make them better-off than the status quo. By contrast, countries for which agreement is less important are more likely to see their priorities get through, because they can credibly threaten not to ratify any agreement far from their preferences.

Nevertheless, countries with intense preferences for agreement can sometimes influence the outcome of the negotiations in a subtle way. In his analysis of the EU Eastern enlargement process, Schimmelfennig (2001) proposes the concept of 'rhetorical action', a set of strategies, played by both the candidate countries and some EU members, consisting in the manipulation of European identity and the accession criteria or in complaints about alleged inequality of treatment between candidate countries. Such concept would provide a better explanation than "standard" liberal intergovernmentalism for the EU's decision to move from association agreements to the offer of membership to the Central and Eastern European countries (CEECs).

Since it involves EU norms and values, rhetorical action may seem to imply a radical deviation from liberal intergovernmentalist assumptions towards a social constructivist perspective. However, as pointed out by Moravcsik and Vachudova (2003), rhetorical action was effective during the enlargement process because economic and geopolitical benefits were present, economic costs were modest (or, at least, sunk) and the overall impact of enlargement on the EU was very limited. Moreover, references to norms and values were used strategically in a rationalist framework. Hence rhetorical action can be better viewed as an extension of liberal intergovernmentalism for the analysis of EU negotiations with third countries than as a departure from it (see Schimmelfennig 2004 for an exhaustive discussion on this point).

There is also another feature of international bargaining which applies specifically to the EU when it negotiates bilateral agreements (Bofinger 1995, Sedelmeier and Wallace 2000). In such a situation, the EU has a strong bargaining power because, before negotiating with a third partner, it needs to find a position acceptable to all its members; subsequently, any change in that position during the negotiations has to win support from each of them again. It is thus difficult that a radical shift in the EU's stance may take place during the negotiations, since it would be very probably resisted by some member states (Forwood 2001, Montanari 2005). ${ }^{2}$

Finally, the likely effects of a specific agreement have to be evaluated. In the case of EUUkraine relations, as well as in the other processes involving EU neighbouring countries, the basic political economy question is whether the degree of integration chosen provides enough incentive to trigger economic and political reform in the partner countries. In this context, a bilateral agreement can be defined as efficient if, in the medium to long term, it may represent an effective external anchor for Ukraine's government to credibly commit itself to reformist policies, aimed at establishing a functioning market economy and a fully-fledged democracy, and to overcome internal opposition to them. This concept will act as a guide in terms of comparing and assessing the different scenarios of integration. 
The liberal intergovernmentalist framework built in this section can be summarised in a few propositions which will constitute the starting point of our analysis in the remaining part of the paper:

- the process leading to an international agreement can be modelled as a two-level game: first, domestic interest groups compete to shape national preferences, then national governments engage in international bargaining where they try to satisfy domestic pressures;

- at the domestic level, national preferences are shaped by economic and geopolitical interests. However, governments enjoy more freedom when the future effects of a specific policy are uncertain or when an issue is not politically or economically sensitive;

- at the international level, (encompassing, in the case of the $\mathrm{EU}$, two dimensions: bargaining among member states and negotiations with Ukraine) the relative bargaining power of governments depends on the importance attributed to agreement: the actors expecting to benefit the most from co-operation are more willing to make concessions (asymmetrical interdependence), but may strategically use EU norms and values to influence the final outcome of the negotiations (rhetorical action). Moreover, the requirement of unanimity among member states strengthens the EU's bargaining power;

- a EU-Ukraine bilateral agreement is efficient if it may effectively spur the Ukrainian government to pursue political and economic reform in the medium to long term.

\section{Three possible scenarios of integration}

In this section three different scenarios for the evolution of EU-Ukraine relations are outlined and compared: Free Trade Area (FTA), fully developed European Neighbourhood Policy (ENP) and EU membership. The aim of this paper is not to predict what will happen in the next few years or in the long run, but rather to evaluate the potential political and economic benefits and costs of each scenario, analysing the main interests at stake for both EU member states and Ukraine.

\subsection{Free Trade Area (FTA)}

This may be defined as a minimalist scenario, because it implies a much lower degree of integration than the other two. An FTA would entail a complete liberalisation of trade in both manufactured and agricultural goods, which would require the abolition of special provisions for sensitive industrial sectors (steel and textiles) and of the protectionist regime governing agricultural products. To understand the issues at stake, we need to examine the present EUUkraine trade relations in detail. According to Eurostat figures, over the last decade EU-15 trade with Ukraine grew quite steadily from roughly $€ 2$ billion for both imports and exports to $€ 7$ billion for exports and $€ 4.5$ billion for imports; figures are about 50 per cent higher for the EU-25. In both cases, the EU trade surplus has been widening significantly.

Absolute values, however, do not reveal much about the relevance of Ukraine as a trading partner of the EU, which can be better assessed by examining the evolution of the share of total EU external trade made with that country. Figure 1 shows that it has only increased modestly since the mid-1990s; at present, barely 0.4 per cent of EU-15 imports and 0.7 per cent of its exports come from or go to Ukraine. In this case too, figures for the EU-25 are roughly 50 per cent higher. 
Figure 1: EU trade with Ukraine as a percentage of Total EU external trade

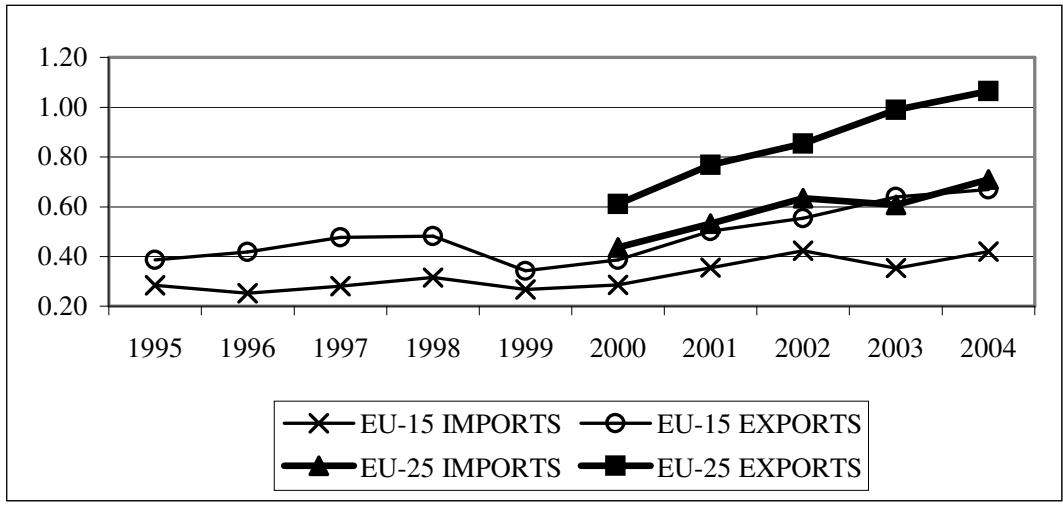

Source: Author's calculations based on Eurostat data

While one can thus conclude that Ukraine accounts for an extremely small share of EU external trade, Figure 2 shows that, by contrast, the EU has become a very relevant trading partner for Ukraine. In the mid-1990s, less than 15 per cent of both Ukraine's imports and exports originated from or went to the EU, whereas, after the 2004 enlargement, these shares have reached 30 per cent. The EU has now become the most important market for Ukraine's exports, surpassing the Community of Independent States (CIS), whose share has steadily declined in the last few years and which is still Ukraine's main supplier (providing about 50 per cent of its imports), chiefly because of energy supplies from Russia.

Figure 2: Ukraine's trade with the EU and the CIS as a percentage of Ukraine's external trade*

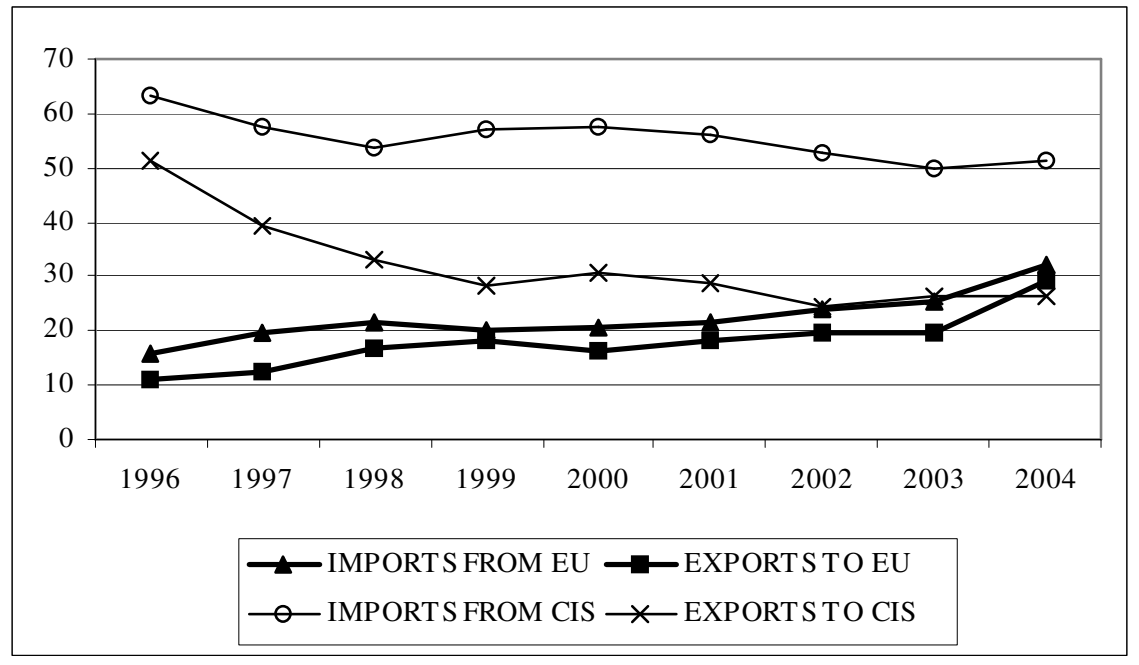

*data from 1996 to 2003 refer to the EU-15; data for 2004 are for the EU-25 Source: State Statistics Committee of Ukraine

This is a clear example of asymmetrical interdependence: Ukraine may obtain much larger benefits than the EU from the establishment of an FTA. After analysing aggregated flows, it is necessary to disaggregate trade, first by sectors then by countries, with a view to identifying possible more specific interests at stake.

EU exports to Ukraine are concentrated in more capital intensive and technologically advanced products (especially machinery), where the EU enjoys large surpluses (Table 1). Also 
in sensitive products, such as textiles and clothing, the EU trade balance is positive. The main imports, on the contrary, are represented by energy, a sector registering quite a large deficit, and agricultural products, where, however, the EU deficit is much smaller.

Table 1: EU trade with Ukraine by main sectors in 2004 (€ million)

\begin{tabular}{llll}
\hline & EU Imports & EU Exports & Balance \\
\hline Machinery & 341 & 3139 & +2798 \\
Chemicals & 489 & 1565 & +1075 \\
Transport equipment & 247 & 1265 & +1018 \\
Textiles and clothing & 492 & 764 & +272 \\
Agricultural products & 855 & 680 & -175 \\
Energy & 1001 & 102 & -898 \\
\hline
\end{tabular}

Source: Eurostat

Some interesting conclusions can be reached by further disaggregating trade flows and examining the pattern of Ukraine's comparative advantage in trade with the EU. It has been shown that, not very surprisingly, Ukraine's comparative advantages in exports are concentrated in just a few sectors: raw materials, agricultural products, iron and steel and some transport equipment (locomotives); among them, only cereals constitute more than 10 per cent of total EU imports in that category (Montanari 2006). Therefore, full liberalisation of imports from Ukraine, also in sectors deemed sensitive (agricultural products, textiles and steel) could be very beneficial to it, because it could better exploit its pattern of comparative advantage, without being a major threat for specific sectors of the EU economy.

Among EU member states, Italy is the main importer from Ukraine ( 23 per cent of total EU imports), followed by Germany and Poland, whilst Germany is the major exporter (it makes 28 per cent of total EU exports to Ukraine), followed by Poland and Italy (Table 2). Both economic dimension and geographical proximity clearly determine the positions in Table 2. Germany, Italy and Poland are large countries located quite close to Ukraine (Poland is also the member state sharing the longest border with it). Smaller countries like Hungary and the Czech Republic exploit their proximity to Ukraine and precede larger but remote countries, such as the United Kingdom (UK) or Spain.

Table 2: EU trade with Ukraine by main partner countries (2004)

\begin{tabular}{llll}
\hline EU IMPORTS & EU EXPORTS & \\
\hline Country & $\begin{array}{l}\text { Share of EU imports from } \\
\text { Ukraine }\end{array}$ & Country & $\begin{array}{l}\text { Share of EU exports to } \\
\text { Ukraine }\end{array}$ \\
\hline Italy & & & \\
Germany & $23.38 \%$ & Germany & $28.49 \%$ \\
Poland & $12.57 \%$ & Poland & $15.87 \%$ \\
Hungary & $11.78 \%$ & Italy & $10.54 \%$ \\
Czech Republic & $7.55 \%$ & France & $5.58 \%$ \\
Spain & $6.09 \%$ & Netherlands & $5.20 \%$ \\
Slovakia & $5.32 \%$ & Hungary & $4.79 \%$ \\
Austria & $4.50 \%$ & Austria & $3.67 \%$ \\
France & $4.24 \%$ & Czech Republic & $3.58 \%$ \\
Netherlands & $4.03 \%$ & Belgium & $3.49 \%$ \\
\hline
\end{tabular}

Source: author's calculations based on Eurostat data 
Potential benefits, even if quite limited, from trade liberalisation seem thus to accrue mainly to the CEECs, Italy and Germany. The relevance of trade flows and geographical proximity thus determine the intensity of EU countries' interest in the creation of an FTA. Possible costs could arise if some EU members' exports had to face a strong risk of competition from Ukraine. In that case, national producers would be against liberalisation and would try to induce their governments to resist it. However, the previous analysis suggests that, at present, no serious threat from trade integration with Ukraine exists for any EU country's economy.

To summarise this section's findings, EU-Ukraine trade relations are marked by a strongly asymmetrical interdependence: Ukraine's economy could get large benefits from the creation of an FTA, whereas benefits for the EU would be small and concentrated in a few countries (the CEECs, Italy and Germany). Potential costs for the EU, in terms of more competitive pressures for specific sectors or countries, would not be significant. Hence, according to this paper's liberal intergovernmentalist model, trade liberalisation is an issue of low political salience for the EU: it should not face a strong opposition from any member state and might represent a realistic medium-term objective. ${ }^{3}$

\subsection{European Neighbourhood Policy (ENP)}

While an FTA may be a medium-term goal, the second scenario we outline is to be considered as a long-term prospect. It can be briefly defined as "FTA plus the other three freedoms of movement (services, capital and persons)" and corresponds to a full exploitation of the opportunities provided by the ENP. It would entail a degree of participation in the Single Market (and therefore of economic integration) comparable to the present EEA. ${ }^{4}$

The benefits from liberalisation of trade in services are widely recognised: greater competition can lead to efficiency gains in both the services sector itself and the other sectors of the economy relying on services as an input. Moreover, when liberalisation involves areas with different levels of economic development, technology transfer from the most advanced countries to the least advanced ones (for instance, via foreign direct investment) can be a significant source of additional growth for the latter (Mattoo et al. 2001). Services liberalisation necessarily require a process of regulatory harmonisation. The rationale for it is to overcome the effects of non-tariff barriers to trade such as standards and regulations imposed for environmental, health, safety or consumer protection reasons, which have become more and more relevant in determining actual market access (Brenton and Manchin 2003).

The very close link between trade in services and foreign direct investment (FDI) raises the issue of free movement of capital. Liberalisation in this field could bring large efficiency gains to Ukraine's economy, which is highly dependent on the EU as a source of FDI. Indeed data from Eurostat and the State Statistics Committee of Ukraine indicate a very strong asymmetrical interdependence: in 2003, 56 per cent of Ukraine's inward FDI stock came from the EU-25, representing, however, only a tiny share ( 0.05 per cent) of EU-25 total stock of outward FDI.

In order to actually reap the potential benefits from freedom of movement of services and capital, Ukraine would have to make considerable effort in implementing politically sensitive reforms. Regulatory harmonisation in the context of the ENP would simply mean that Ukraine should adopt EU standards. Capital liberalisation would be productive only if accompanied by sound economic policies, at both the macroeconomic and the microeconomic level, including fiscal and monetary discipline and a proper regulatory environment (European Commission 2005a).

A detailed analysis of the problems currently faced by Ukraine's economic system is far beyond the scope of this paper. We just mention that, contrary to what has happened to the CEECs, the process towards the creation of a functioning market economy has so far been very slow and largely unsuccessful: the political economy of transition in Ukraine has been marked by plenty of opportunities for rent-seeking, promptly exploited by the so-called 
'oligarchs', a small number of people who gained and still retain the control of most of the manufacturing and services sectors (Pynzenyk 2000, Sundakov 2000, Sellar and Pickles 2002, Åslund 2005, Kuzio 2005). Taming oligarchs' power is therefore the most challenging task for a reform-minded government eager to achieve a high degree of integration with the EU.

According to the theoretical framework as set out in this paper, the long-term nature of the ENP prospects represents an example of uncertainty about the future effects of specific policies. Given the economic disparities and the differences in regulatory environment between the EU and Ukraine, liberalisation of trade in services and of capital movement could only be achieved very gradually. This might reduce the incentives for radical economic and political reform in Ukraine. Lobbying groups in sectors sheltered from competition (such as services) may use their influence on populist politicians with a view to slowing down the reform process (Shumylo 2006).

While the previous issues should not be of particular concern for EU public opinion, the free movement of people is certainly very sensitive. The distribution of immigrants from Ukraine in the EU is reported in Table 3. ${ }^{5}$ The largest number of Ukrainian citizens reside in Germany $(116,000)$, where, however, they only represent 1.6 per cent of total foreign population. In the Czech Republic, Poland and Slovakia (three countries located near Ukraine), the Ukrainians constitute quite a large share of immigrants (from 25 per cent to 16 per cent of total).

Table 3: Ukrainian citizens resident in selected EU member States (2002)

\begin{tabular}{lll}
\hline & $\begin{array}{l}\text { Ukrainian citizens } \\
\text { (thousands) }\end{array}$ & $\begin{array}{l}\text { Share of total foreign } \\
\text { population }\end{array}$ \\
\hline Czech Republic & 59.1 & $25.5 \%$ \\
Poland & 9.9 & $20.1 \%$ \\
Slovakia & 4.7 & $15.9 \%$ \\
Portugal & 62.0 & $15.0 \%$ \\
Hungary & 9.9 & $8.5 \%$ \\
Lithuania & 1.6 & $7.7 \%$ \\
Greece & 13.6 & $1.8 \%$ \\
Germany & 116.0 & $1.6 \%$ \\
Netherlands & 2.2 & $0.3 \%$ \\
\hline
\end{tabular}

Source: OECD (2005)

Some opposition to free movement of Ukrainian nationals may thus be expected to come especially from neighbouring countries, even if, among EU member states, they would be those reaping the largest benefits from economic integration with Ukraine. Their position mirrors the situation faced by Austria and Germany with regard to the 2004 enlargement (Boeri and Brucker 2002). The EU could exploit its superior bargaining power and impose restrictions in the field of labour movement, with a view to reassuring public opinion in those Member States most affected by Ukrainian immigration. The temporary restrictions to freedom of movement for CEEC nationals, even after their countries' accession to the EU, imposed by most "old" member states may constitute a precedent for similar or more stringent measures applicable to Ukraine.

On the whole the long-term nature of the ENP prospects might help overcome opposition within the EU with regard to the free movement of people. This is another example of uncertainty about the future effects of specific policies. At the same time, as in the case of liberalisation of trade in services and of capital movement, the incentives for economic and political reform in Ukraine would be reduced. 


\subsection{EU accession}

Ukraine has not been granted the prospect of EU membership so far; therefore any scenario contemplating EU accession is not only long-term, but also very hypothetical. EU membership implies a higher degree of economic integration than the previous scenarios and introduces new significant elements of political integration. It is defined in this paper in a stylised way as "ENP plus Common Agricultural Policy (CAP) and structural policies plus participation in EU institutions".

In the economic field, the EU budget should be modified to include CAP payments and Structural Funds attributed to Ukraine. The historical precedent of the 2004 enlargement suggests two reflections. Firstly, some opposition could come from two groups of countries: net contributors to the budget (such as Germany and the Netherlands), which should pay the largest share of the cost of Ukraine's accession, and the present poorest member states (the CEECs) fearing to lose part of the Structural Funds. Secondly, the actual cost of enlargement to Ukraine could be accommodated without any disruptive impact on the budget. To support the latter claim, one can make a simple illustrative calculation, whose methodology is described in detail in the Annex. The maximum net cost of a hypothetical enlargement to Ukraine in 2005 could reach $€ 2.46$ billion, corresponding to only 0.025 per cent of EU-25 GDP. Moreover, the EU could easily exploit its superior bargaining power and the asymmetrical interdependence in its relations with Ukraine in order to impose transition periods or temporary restrictions that Ukraine would be almost obliged to accept without modifications. In the political field, Ukraine's participation in the EU institutions would exert some impact especially on the Council of Ministers and the European Parliament. With 48 million people, this country would account for roughly 10 per cent of the EU population and would get a number of votes and seats similar to that of France, Italy and the UK, becoming a significant player in EU decision-making processes. The main political issue raised by Ukraine's accession would concern however the completion of its process of stabilisation and democratisation: according to the Copenhagen Criteria, Ukraine should guarantee 'democracy, the rule of law, human rights and respect for and protection of minorities' (European Council 1993) to be considered for EU membership. The successful creation of a fully-fledged democracy would clearly bring large geopolitical benefits to the EU, especially to Ukraine's neighbouring countries. This was already evident during the 2004 Orange Revolution, when Poland and Lithuania acted as "drivers" in spurring the EU to support it, whilst France and Germany were more reluctant to intervene because they feared to worsen their relations with Russia (Emerson et al. 2005, Nemyria 2005).

Nevertheless, Ukraine has not been recognised as a potential candidate for membership yet. After the 2004 Eastern enlargement and the rejection of the Constitutional Treaty in France and the Netherlands in 2005, the EU seems to be very wary of new enlargement rounds (other than the scheduled accession of Bulgaria and Romania). The outcome of the accession negotiations launched in October 2005 with Turkey (another large and poor country at the borders of Europe), which has been granted the prospect of EU membership, is still openended and might fall short of accession (European Commission 2005e). Moreover, the concept of 'absorption capacity' of the EU was recently stressed by the European Council, even if it has not become (at least, not yet) a new formal criterion for accession (European Council 2006).

Here there is wide room for rhetorical action to be played by both Ukraine and those member states, like Poland and the other CEECs, expecting to obtain the largest geopolitical payoff from Ukraine's accession. Indeed, all the conditions stressed by Moravcsik and Vachudova (2003) for successful rhetorical action would be in place in the case of EU's enlargement to Ukraine: geopolitical benefits would be present, economic costs would be low and the overall impact of enlargement on the EU would be very limited.

Strategies such as emphasising Ukraine's European identity and underlining its satisfactory performance with regard to the accession criteria may help to strengthen the bargaining power of the actors in favour of opening the EU's door to that country. As regards Ukraine's 
European identity, the Ukrainian government has already resorted to rhetorical action. For instance, in 2005 Oleg Rybachuk, minister for European integration, declared: 'We will never agree to this neighbourhood status as indefinite. It goes against our strategy, against our priorities and against public opinion. [...] We believe that it is the sacred right of every European nation to submit that application and Ukraine is not an exception, this is our natural right' (European Voice 2005).

A good performance by Ukraine with regard to the accession criteria may clearly enhance its prospect of membership. If Ukraine fulfils the requirements for EU membership, but some member states still manifest the will to block any enlargement involving a large and poor country, rhetorical action may play an important role, in particular by demanding the respect of the principle of equal treatment between Ukraine and the CEECs. In such a case a rejection of Ukraine's application could appear as an unfair decision.

To evaluate the present performance of Ukraine with regard to the respect of economic and political Copenhagen criteria, we choose two frequently used indicators: the Index of Economic Freedom by the Heritage Foundation (Heritage Foundation 2006) and the Freedom in the World Index by the Freedom House (Freedom House 2005). The former ranks countries' economies on a scale from 1 (completely free) to 5 (completely repressed). In 2005, Ukraine scored 3.24 and was still classified as 'mostly unfree' economy. According to the latter, the score attributed to a country's political system may range between 1 (completely free) and 7 (completely repressed). Ukraine's score in 2004 was 4 for 'Political Rights' and 3 for 'Civil Liberties' and the country was judged only 'partly free'. 6

Ukraine clearly has still a long way to go to meet the conditions required for EU membership. However, it has also to be noticed that, because of asymmetrical interdependence, Ukraine would be willing to accept a number of compromises (such as temporary restrictions or transition periods) in order to reach the fundamental goal of EU membership.

\subsection{A comparison}

A comparison of the three scenarios permits to examine their efficiency, as defined in Section 3. An FTA is a medium-term objective which does not need deep reforms in Ukraine to be achieved; hence it cannot be considered as efficient. On the contrary, a fully developed ENP does require a long-term process of thorough economic and political reform, but, unfortunately, does not provide Ukraine with enough incentive to realize it. Indeed, Ukraine would have to adopt the acquis communautaire concerning the Single Market without reaping the benefits of EU membership, such as the CAP, the Structural Funds and participation in the EU decision-making process. In their absence, it would be unlikely that the Ukrainian government might build a broad consensus in public opinion for difficult reforms facing strong opposition from the powerful domestic groups controlling most of the economy. Therefore, only the prospect of EU membership can act as an effective external anchor for radical political and economic reform.

It follows that EU membership is the only efficient scenario: the ENP cannot be a credible alternative to it for Ukraine in the long run. Actually the EEA, the model of economic integration to which a fully developed ENP would tend, aims to provide a strong link to the EU for some Western European countries which do not want to join it (at present, Norway, Iceland and Liechtenstein), but is not intended as a substitute for membership for countries that, by contrast, wish to enter the EU. Hence a fully developed ENP is a very unlikely scenario; as a consequence, the long-term outcome of the integration process will probably be either more modest (remaining essentially limited to the creation of an FTA) or more ambitious, leading therefore to EU accession. 


\section{Conclusions}

This article has proposed a liberal intergovernmentalist framework for the analysis of Ukraine's prospects of integration with the EU with a view to evaluating the main benefits and costs associated to three possible scenarios: FTA, fully developed ENP and EU accession. Its main findings can be briefly summarised as follows. First, gains from integration would be asymmetrically distributed and would mostly accrue to Ukraine, while the main obstacles would come from political rather than economic reasons. Second, the ENP does not represent a credible long-term alternative to EU membership for Ukraine; thus the likely outcome of the integration process should consist either in the mere creation of a free trade area or in EU accession.

Finally, a relevant issue not discussed in this article concerns the possible influence of relations with Russia on Ukraine's integration with the EU. However, the trade-off between integration with the EU and integration with Russia may well turn out to be more apparent than real. Ukraine's rapprochement with the EU does not exclude the maintenance of close economic ties with Russia as long as integration between the EU and Russia proceeds too. In this latter field, a significant step forward was achieved in May 2005 with the agreement on a road map aiming to build Common Spaces in four areas: economy; freedom, security and justice; external security; research education and culture (European Commission 2005b). Moreover, Russia's cooperation might also be beneficial to EU-Ukraine relations themselves and even help Ukraine to avoid "knocking on the EU's door" indefinitely.

\section{Annex. The cost of Ukraine's membership}

In estimating the cost of Ukraine's membership for the EU budget, we apply a simple methodology similar to that used by Gros (2005) in the case of Turkey. The approach consists in calculating the net benefits from the EU budget that Ukraine would receive under current rules if today it were a EU member. At first sight, this might seem somewhat unrealistic, but it avoids the problem of making necessarily arbitrary assumptions about Ukraine's possible accession date, the evolution of EU budgetary rules, and future economic growth rates of both the EU and Ukraine. Taking into account that the goal of this exercise is merely to indicate the possible order of magnitude of the cost of Ukraine's membership, simplicity and transparency may be preferred to more sophisticated methods.

The two fundamental items of the EU budget are the CAP and the Structural Funds. The calculations for agriculture are potentially quite complex, since we should consider the output structure of agriculture in Ukraine. However, we can avoid that by using an indirect approach, based on the ratio between CAP support and agricultural production. At present, the CAP absorbs 0.5 per cent of EU-25 GDP and the value added produced by agriculture is about 2.5 per cent of EU-25 GDP. Therefore we may assume that European farmers get at most 20 per cent of their value added from the CAP. To simplify the calculations further, suppose that Ukraine is treated exactly like one of the old EU-15 members and is not subject to the temporary restrictions applied to the new members. Finally, agriculture produces 14 per cent of Ukraine's GDP and the Ukrainian economy accounts for 0.45 per cent of EU-25 GDP. Consequently, the maximum amount of CAP support to Ukraine would be 0.013 per cent $(=20 \% * 14 \% * 0.45 \%)$ of EU-25 GDP.

As regards the Structural Funds, the calculation is straightforward. Under existing rules, the amount of Structural Funds that a country may receive is capped at 4 per cent of its national GDP and, as before, the Ukrainian economy accounts for 0.45 per cent of EU-25 GDP. Therefore, Ukraine would get 0.018 per cent $(=4 \% * 0.45 \%)$ of EU- 25 GDP at most.

Since the EU budget approximately equals 1.2 per cent of EU-25 GDP, this implies that Ukraine's contributions to it would amount to about 1.2 per cent of its GDP, which, as above, corresponds to 0.45 per cent of that of the EU-25. Therefore Ukraine's contributions to the EU budget would represent 0.0054 per cent $(=1.2 \% * 0.45 \%)$ of EU-25 GDP. After subtracting 
contributions from total receipts, Ukraine's maximum total net receipts from the EU budget would then reach 0.025 per cent of EU-25 GDP. The main findings of these calculations are summarised in Table A.1. Since EU-25 total GDP presently amounts to $€ 10,270$ billion, the annual net cost of Ukraine's membership would be $€ 2.46$ billion.

Table A.1: The cost of Ukraine's membership of the EU (in \% of EU-25 GDP)

\begin{tabular}{ll}
\hline CAP & $0.0126 \%$ \\
Structural Funds & $0.0179 \%$ \\
Total Receipts & $0.0305 \%$ \\
Total Contributions & $-0.0054 \%$ \\
\hline TOTAL NET RECEIPTS & $\mathbf{0 . 0 2 5 1 \%}$ \\
\hline
\end{tabular}

Source: author's calculations

\section{Notes}

1 The geographical coverage of the ENP includes some former Soviet republics (Ukraine, Armenia, Azerbaijan, Belarus, Georgia and Moldova) and countries in the Mediterranean region (Algeria, Egypt, Israel, Jordan, Lebanon, Morocco, the Palestinian Authority, Syria and Tunisia).

2 This remark follows from the logic of two-level games, firstly proposed by Putnam (1988). Using his terminology, the requirement of unanimity among its member states greatly restricts the EU's range of acceptable outcomes (its "win-set") when it negotiates with a third country, implying that the final agreement will tend to be quite close to the EU's position.

3 However, as mentioned in Section 2, the necessary precondition for the opening of negotiations for an FTA is Ukraine's accession to the World Trade Organization.

${ }^{4}$ Here we abstract from the institutional provisions governing the EEA. For more details on this subject, see Vahl (2005).

${ }^{5}$ Data were not available for all EU member states.

${ }^{6}$ Data on political freedom in Ukraine for 2005 are not available yet.

\section{References}

Åslund, A. (2005). 'The Economic Policy of Ukraine after the Orange Revolution', Eurasian Geography and Economics, 46 (5), pp. 327-353.

Boeri, T. and Brucker, H. (2002). The Impact of Eastern Enlargement on Employment and Labour Markets in the EU Member States. Berlin, European Integration Consortium.

Bofinger, P. (1995). 'The Political Economy of the Eastern Enlargement of the EU', CEPR Discussion Paper, 1234.

Brenton, P. and Manchin, M. (2003). 'Trade Policy Issues for the Euro-Med Partnership', Centre for European Policy Studies Middle East \& Euro-Med Project Working Paper, 7.

Brenton, P., Sheehy, J. and Vancauteren, M. (2001). 'Technical Barriers to Trade in the European Union: Importance for Accession Countries', Journal of Common Market Studies, 39 (2), pp. 265284.

Emerson M., Aydin, S., Noutcheva, G., Tocci, N., Vahl, M. and Youngs, R. (2005). 'The Reluctant Debutante - The EU as a Promoter of Democracy in its Neighbourhood', in M. Emerson (ed.), Democratisation in the European Neighbourhood, Brussels, CEPS, 169-230.

European Commission (2003). Wider Europe - Neighbourhood: A New Framework for Relations 
with our Eastern and Southern Neighbours, COM(2003) 104 final, 11 March.

European Commission (2004b). European Neighbourhood Policy Strategy Paper, 12 May.

European Commission (2005a). 'European Neighbourhood Policy: Economic Review of ENP Countries', European Economy Occasional Papers, 18.

European Commission (2005b). 'EU-Russia Summit, Moscow, 10 May 2005', http://europa.eu.int/comm/external_relations/russia/summit_05_05/index.htm

European Commission (2005c). 'EU-Ukraine - Strengthening the Strategic Partnership', Press Release, MEMO/05/106, 29 March.

European Commission (2005d). 'EU-Ukraine Trade Relations', http://europa.eu.int/comm/ external relations/ukraine/intro/index.htm.

European Commission (2005e). 'Negotiating Framework for Turkey', http://europa.eu.int/comm/enlargement/docs/pdf/st 20002 en05 TR framedoc.pdf.

European Council (1993). Copenhagen European Council. Presidency Conclusions, 22 June.

European Council (2006). Brussels European Council. Presidency Conclusions, 16 June.

European Voice (2005). Ukraine set to consider EU application, 28 April.

Forwood, G. (2001). 'The Road to Cotonou: Negotiating a Successor to Lomé', Journal of Common Market Studies, 39, No. 3, 423-442.

Freedom House (2005). Freedom in the World 2005, http://www.freedomhouse.org/ ratings/index.htm.

Gros, D. (2005). 'Economic Aspects of Turkey's Quest for Membership', CEPS Policy Brief, 69. Heritage Foundation (2006) 2006 Index of Economic Freedom, http://www.heritage.org/research/features/index/ downloads/2006lndex.pdf.

Keohane, R. and Nye, J. (1977). Power and Interdependence, Boston, Little, Brown.

Kuzio, T. (2005). 'Ukrainian Economic Policy after the Orange Revolution: A Commentary on Åslund's Analysis', Eurasian Geography and Economics, 46 (5), pp. 354-363.

Mattoo, A., Rathindran, R. and Subramanian, A. (2001). 'Measuring Services Trade Liberalisation and Its Impact on Economic Growth: An Illustration', World Bank Policy Research Working Paper, 2655.

Montanari, M. (2007). 'The Barcelona Process and the Political Economy of Euro-Mediterranean Trade Integration', Journal of Common Market Studies, forthcoming.

Montanari, M. (2006). 'Knocking on the EU's Door: The Political Economy of EU-Ukraine Relations', University of Modena and Reggio Emilia Department of Economics Working Paper, 529.

Moravcsik, A. (1993). 'Preferences and Power in the European Community: A Liberal Integovernmentalist Approach', Journal of Common Market Studies, 31 (4), pp. 473-524.

Moravcsik, A. (1998). The Choice for Europe: Social Purpose and State Power from Messina to Maastricht, London: UCL Press.

Moravcsik, A. and Vachudova, M.A. (2003). 'National Interests, State Power, and EU Enlargement', East European Politics and Societies, 17 (1), pp. 42-57. 
Moshes, A. and Haukkala, H. (2004). Beyond the Big Bang: The Challenges of the EU's Neighbourhood Policy in the East, Helsinki, Finnish Institute for International Affairs.

Nemyria, H. (2005). 'The Orange Revolution: Explaining the Unexpected', in M. Emerson (ed.), Democratisation in the European Neighbourhood, Brussels, CEPS, 53-62.

OECD (2005). Trends in International Migration, Paris, OECD Publishing.

Putnam, R. (1988). 'Diplomacy and Domestic Politics: the Logic of Two-level Games', International Organization, 42 (3), pp. 427-60.

Pynzenyk, V. (2000). 'How to Find a Path for Ukrainian Reforms', Russian and East European Finance and Trade, 36 (1), pp. 59-77.

Schimmelfennig, F. (2001). 'The Community Trap: Liberal Norms, Rhetorical Action, and the Eastern Enlargement of the European Union', International Organization, 55 (1), pp. 47-80.

Schimmelfennig, F. (2004). 'Liberal Intergovernmentalism', in A. Wiener and T. Diez (eds.), European Integration Theory. Oxford: Oxford University Press, pp. 75-94.

Sedelmeier, U. and Wallace, H. (2000). 'Eastern Enlargement. Strategy or Second Thoughts?', in $\mathrm{H}$. Wallace and W. Wallace (eds.), Policy-Making in the European Union. Oxford: Oxford University Press, pp. 427-460.

Sellar, C. and Pickles, J. (2002). 'Where Will Europe End? Ukraine and the Limits of European Integration', Eurasian Geography and Economics, 43 (2), pp. 123-142.

Shumylo, O. (2006). 'Ukraine and the European Neighbourhood Policy', CEPS Working Document, 240.

Sundakov, A. (2000). 'Liberalization, the Legal Framework and Market Indicators in Ukraine', Eastern European Economics, 38 (2), pp. 6-17.

Vahl, M. (2005). 'Models for European Neighbourhood Policy. The European Economic Area and the Northern Dimension', CEPS Working Document, 218. 